BALATONI, MONIKA

balatoni.monika@uni-nke.hu

PhD student in Public Administration Sciences - University of Public Service

ORCID: 0000-0001-8482-7838

\title{
The impact of the Parliament on country branding and national identity
}

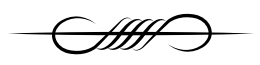

\begin{abstract}
The 21st century is an era of globalization, of changes and transformations of cultures and national identity patterns representing different values and value systems. As a result of these transformations, new concepts, national symbols, and even ceremonies and ceremonial orders may be born, and the process of enculturation requires an increasingly emphatic and well-thought-out strategy from the leaders of nation-states. The national theme has become a determining force in Hungary in recent decades. The Hungarian Parliament has always played a significant role in the historical and cultural past and memory of Hungarian society. The Parliament is one of the most famous buildings for both tourists and Hungarians. In October 2011, the Parliament passed a law declaring Kossuth Square a national memorial. On the occasion of the ten-year anniversary, it is possible to examine what it has achieved in the Hungarian national enculturation as well as in the judgment of the Hungarians, in the self-representation of the country.
\end{abstract}

\section{KEYWORDS}

national identity, the House of Parliament, country branding, enculture

DOI 10.14232/belv.2021.4.3

https://doi.org/10.14232/belv.2021.4.3

Cikkre való hivatkozás / How to cite this article: 
Balatoni, Monika (2021): The impact of the Parliament on country branding and national identity. Belvedere Meridionale vol. 33. no. 4. 30-52. pp

ISSN 1419-0222 (print)

ISSN 2064-5929 (online, pdf)

(Creative Commons) Nevezd meg! - Így add tovább! 4.0 (CC BY-SA 4.0)

\section{INTRODUCTION}

The most relevant symbol of tourism taking place in Hungary including its capital is the House of Parliament. The Building of the National Assembly in Hungary plays a direct and indirect role in the forming of a picture of the country; as a tourist attraction it is seen by a lot of visitors frequently, as well as it functions as an emblem representing Hungary and Budapest. In the course of conducting my research the fact revealed itself that experts have paid very few attention to the role the House of Parliament plays in the shaping of nation image. The goal of this present writing is to compensate for this shortcoming.

What role does the Building of the National Assembly and its immediate environment play in the process of nation branding in our homeland? What ways and methods would be of help to bring the Parliament Building examined in its micro-environment closer to nation image as a whole?

My hypothesis is based on the premise that the House of Parliament in Hungary plays an outstanding role in shaping Hungarians' national identity and the picture foreigners form about the country.

Firstly, it is important to lay down conceptual framework, after which I'll take the historical context in which the nation image was being shaped under scrutiny. For analysing nation image I'll take nation branding goals emanating from marketing expert Árpád Ferenc Papp-Váry as a basis, then I'll show the inner identity forming force of the House of Parliament and that how much it shapes the country's tourism, closing the line of my thoughts with a summary. It is important to emphasise that I'll examine the House of Parliament as a cultural venue.

How? To provide an answer to this question, it is necessary to ask some more and clarify the answers given to them.

Members of society are carriers of culture. In this fact the House of Parliament as the most well-known building in Hungary and a multifunctional institution, not only the history but also the cultural background of which is considerable, can play a role.

Acquiring national culture provides a basis for the forming of national identity even today. In international literature this process is called 'national enculturation'. In today's information society national culture finds its way to get to members of society through several mediums other than school, such as, community elements, experiences, effects, festivals, as well as national memorial places that gain from a wider social discourse.

In domestic literature Ferenc Pataki was the first to formulate the following: "It seems reasonable to make a conceptual differentiation between self and identity; self is a complex, 
multifunctional system that includes the knowledge of a person about himself. In this multifunctional system societal identities (with national identity among them) create a separate system referring to the knowledge of a person relating to himself, emanating from society. Everyone has this." (РATAKI 2001.)

\section{Conceptual Overview Of Nation Image As An Element Of SELF-REPRESENTATION}

Marketing experts have long made a conceptual differentiation between 'image' and 'branding' Image is the picture formed in the recipient not by traditional marketing tools but by mouth advertisement, training occasions, scholarships or media tools; a sort of a mixture made up of inner opinion, consciousness and impressions. In her lecture note written about tourism marketing Boglárka Kozma circumscribes the definition of 'image' as follows: "The general, almost not recognised source of information that falls out of the direct effect of tourism designers." (Kozma 2004. 302.)

By contrast, brand is a result of a reality constructed from outside, the message of which is made up by marketing experts. It includes everything that "others" think about the given item, thus used as a tool for differentiation.

The definition emanating from marketing experts Philip Kotler and Kevin Lane Keller explains the concept of brand as follows: "a brand can be a name, an expression, a token, a symbol, a design or a combination of these that serves the function of identification of a product or a service offered by a seller or a group of sellers or their differentiation from those offered by competitors" (KoTLER - KELLER 2006. 954.). Considering this, anything can be a brand; a person, a service or even a country. A lecture note used at Budapest Business School uses a clear-out definition for branding that given its simplicity formulates an eternal truth concerning every area: "brand is a thought planted in consumers' mind" (Kozma 2004. 303.).

A main difference between 'nation image' and 'nation branding' lies exactly in that while image is based on an inner "we-consciousness", i.e. identity, branding is a result of a process directed from outside. A brand created through nation branding is what shapes feelings and thoughts relating to a given state. On the other hand, nation image is a mixture compounded with perceptions and stereotypes and is considerably more difficult to influence (HUSZTI 2003). The central message of nation brand can be devoid of stereotypes, a part of a nation image, or a complementation of it, it is not necessarily a concept defined in contrast to it (tradeforum.org, 2018). By applying a proper nation branding technique nation image can be formed and channelled in a desirable way.

The concept of nation image was defined in the late twentieth century, although it had been applied much more earlier. International realignment following World War II altered power relations, putting nearly two hundred states in the place of previously existing quasi-fifty. Today, owing to the effects of globalisation and development in information communication technologies, it is easy to gain information about current happenings in Bhutan or even Argentina. The picture formed of a country and the messages attached to it arrive to the online space through 
a direct way, exerting a continuous effect to each other, this way doubling the effect of every message (PAPP-VÁRY 2009. 8-9.). It is particularly true nowadays when questions concerning nation state have come into the limelight.

That is why so-called "soft" power-that in contrast to economic and hard, military factors means the benefit coming from the area of sport, culture and science-can have a considerable role. A professor at Harvard University, Joseph Nye considers that soft power gained an outstanding importance in the twenty-first century given that owing to the effects of globalisation promoting standardisation a nation state is not any more able to differentiate itself from its competitors, the other ones (SzÖRÉNYI 2009). This is what makes a complex content being able to differentiate from competition, to mark products and services in a way through the process of branding necessary to create and communicate. Nation image including nation branding have to hold its own in this resulting situation.

When designing nation image strategies decision makers and experts often use a classic technique applied in corporational environment, although country as a brand carries several special traits. The most important attribute and at the same time difference is that while classic brand comes with ownership relations, state has no real owner, each and every citizen and society as a whole can be attached to ownership, thus being able to exert an influence on the brand. The situation is convoluted by that in the case of republic as a state form decision makers of the country are representatives chosen through elections who design nation image strategy instead of the whole of the citizens (PAPP-VÁRY 2003. 7.). What means another difficulty in this "system" is that strategy making requires a longer-term perspective than most of the soft powers, efforts invested will pay off only decades later. However, given that democratic systems change every four years, it is difficult to create a strategy that is sustainable for decades, pointing to the same direction. A general tendency is that every new leadership thinks through directions, this way decreasing the efficiency of nation branding.

Therefore, the other considerable difference to traditional brand building is that a firm's brand is directed from up to down, following a so-called "top-down" method. Management on top of the hierarchy defines the direction of branding and executes it or gets it executed by its co-workers and subordinates. In this case, brand consists of some components and finds its way to consumers through a chosen communication channel, in the most efficient way possible. In the mechanism of nation branding these channels of communication aren't operated by a sterile or central coordination to bring the message to recipients, but they are immanent in every citizen's every move (PAPP-VÁRY 2009/b).

When arriving Liszt Ferenc International Airport, options to both border check and getting to the city-Köbánya-Kispest railway station, compartments in metro, the manners presented by the cab driver-all form the first, and most important, impression in visitors coming to Hungary. Already then, a positive or negative picture of the country is beginning to shape, everyday contacts provide unlimited opportunity to image creation.

A classic brand can be built through a well-structured system, can exactly be attached to space and time. An interesting example to changing of a brand name is provided by the case of Burger King. The company's leadership offers the same products and services in Australia as in Europe, with the sole difference that in the former it does that under the brand name "Hungry Jack" (TERRY - FOREST 2008). Nation brand, however, is unchanging; its name cannot be altered 
just as it is the case with geographical location, its development takes place on a much more determined path (PAPP-VÁRY 2009/b). All this testifies that states' leaderships should create their strategies concerning long-term nation image considering and at the same time applying the rules of classic branding.

\section{MeASURing NATiOn IMAGE}

In 2005, a marketing expert Simon Anholt, the coiner of the term 'nation branding' devised a surprising theory for the qualitative analyse of nation image. Anholt examines states by comparing them to each other, this way making the ranking between them possible. His theory is based on a comprehensive opinion-poll drawing conclusions concerning a country's reputation by using representative samples. The questionnaire including fifty questions examines countries using six segments that are the following: nations' culture, politics, business affairs, human resources, investment opportunities and touristic attractions. All these factors together constitute an index published on an annual basis (now by a research company designated for this task), evaluating amongst others Hungary. But before taking a look at Hungary's National Branding Index (NBI), I will now show these six segments which are to be taken into account when measuring a nation's reputation (ANHOLT 2005).

The first dimension is the political environment regarding which the following questions are to be answered: what form of government of the given country has, including the degree of government's competence in leadership, what tools they use and how fair they are, how much room to maneuver they have on the international platform, what kind of an approach they take to human rights issues (NAGY 2008). The second aspect of NBI is centred around economy, particularly export activity, concretely which products of the given country we know, whether we identify a service with the country that offers it. The next NBI factor is tourism which is such a basic element of nation image that its raison d'être has never been questioned by any one of state leaders. Tourism marketing is identified with nation branding in many cases. Mostly, leaderships' fault is rooted in that under the "guise" of nation's reputation building they create advertisements facilitating tourism, however, it takes up only a sixth of nation image. The index here mainly shows what tourist attractions of a given country respondents are aware of, whether they would choose the examined country as a travel destination. Volume of investments and immigration are the fourth dimension in Anholt's Model. This segment means the examination of the attractiveness of a country, not the force emanated from tourism, but that which brings foreigners to work or learn there. This kind of long-term trust is what provides a basis for capital investments. The next aspect focuses on culture and heritage taking intellectual heritage of both current times and long ago under scrutiny, from national value through sport achievements to globally known eternal principles. The last segment, which is the sixth one, refers to a country's people, population: how much they are open, kind and tolerant to their minorities. Basically, the index values reveal how "others", namely foreigners, see us Hungarians, in other words what inner identity, mentality of the given nation has. With regard to NBI Hexagon it is important to highlight that each of the dimensions has the same relevance during research, so the order above in this section doesn't reflect priority. 




Nation Brand Hexagon by Anholt 2005

https://www.branding-institute.com/rated-rankings/anholtgfk-roper-nation-brands-index www.goodcountry.org/simon-anholt/

Hungary was amongst the initially examined 35 countries, having achieved the $23^{\text {th }}$ place after the first round of research, which is a higher ranking than the ones gained by two other countries from the Central East European region, namely Czechia and Poland. Although this counts as an outstanding result comparing to the rest of Central East European countries, it shows that respondents have quite little knowledge about us. The country that had the most positive opinion about us was that of the rising sun, Japan, regarding us as welcoming, diligent and reliable people. However, more than 80 percent of respondents had never been to Hungary, and only half of the rest 20 percent had come to visit our homeland as a tourist. The fact that approximately 12 percent of respondents knew someone from Hungary personally and more than 20 percent of them had bought a Hungarian product is in line with this (Turizmus Bulletin 2006). This proportion is very low for forming an in-depth, relevant opinion of our country.

Hungary's accession to the EU and the fact of democratic transition taken place were important elements in the area of political environment. Countries that have a longer history of democracy as a basic value and practice in their governance all achieved a place nearer to the top of the list than us. Regarding export products and services products churned out by food industry and heavy industry were better known by respondents. We didn't gain a high ranking as a tourist destination, either, having been put to the $26^{\text {th }}$ place in this category. The highest number of people who planned to visit Hungary came from France, Italy and Spain, which viewing the period between 2006-2018 doesn't reflect reality, considering that in the past years Budapest enjoyed quite dynamic tourism with an increase in the proportion of exactly German and Russian visitors. With regard to built heritage Hungary got a better evaluation, respondents found our country wonderful, exciting and predictable. Respondents from Great-Britain, Canada and the US would welcome the opportunity to come to our homeland to work or study. In the subject matter of cultural dimension results showed museums, circuses and sculpture as those representing the most interesting cultural value. 
Since the time examined, i.e. 2006, more than one of these six factors have been showing continuous change. Nation image of Hungary analysed by NBI annually was quite constant in the period between 2008-2011, followed by a decrease in reputation in 2011-2012 in the eye of some nations, for example Mexicans or Italians. In the area of export, governance and culture this situation had been improved, followed by a decline some years later again. We can say that Hungary as a state doesn't have a solid nation image, the picture formed of the country is in a constant move, despite the fact that the process of reshaping a country's reputation takes quite a long time and is influenced by many factors. Simon Anholt saw this phenomenon as unusual, advising that Hungary should pay more attention to its nation image given that it exerts a considerable influence on its business life and international political relations to which continuous fluctuation has a detrimental impact (HAHN 2013).

\section{Nation image Practice in Hungary}

Following the change of regime, although political leadership in Hungary paid a marginal attention to the question of country image in several policies, their approach restricted to tourism. During the time of first free elections, the launching of privatisation and democratic transition decision makers had little capacity to the shaping of the picture formed about the country. Truly though, there was no need for it. Tourism as a sector was an engine of economy, goulash communism having prevailed in previous decades and nostalgic remembrance of it attracted many visitors to our homeland. That time Hungary was the fifth most popular destination in the world. Although tourists' interest to this East European communist exotism and nostalgia turned out to be short-lived, it exerted quite a considerable impact. Very soon, it resulted in the need for creating a complex nation image for the sake of a sustainable tourism.

The turn of the millennium brought the need for putting theory into practice, namely devising the concept for creating a coordinated, comprehensive nation marketing. To accomplish this task, Country Image Centre was called into being. The institution wasn't long-lived, its operation was terminated in 2002 in the crossfire of political debates. The institution fell under the direction of the Political Minister of State for Communication from the Prime Minister's Office, led by István Zoltán Tóth. Its aim was to put a single symbol representing Hungary (such as maple leaf of Canada, windmill of the Netherlands, e-services of Estonia) in the place of interpretations like "horse herd-goulash-plain" and "the most cheerful barrack" (ТóTH 2000. 156.). Without executing an in-depth analysis of problems occurred in the background, I'd only like to highlight that the institution's mission was to shape Hungarians' national identity and foreigners' opinion formed about the country by taking an interdisciplinary approach and harmonising policies (PAPP-VÁRY 2009/a). With the abolishment of Country Image Centre the issue of nation image was redirected to different policies with Government Communications Headquarters set up in Prime Minister's Office having been assigned to deal with it, requiring much less financial and human resources (BALATONI 2018).

During this period two important conferences were delivered; the first one, organised by the state in the context of Hungary's accession to the EU, took place in 2004, the other was organised by a foundation known as DEMOS Hungary, with the title "Country Branding - International 
Identity and Image". These initiatives directed participants' attention to the relevance of nation image, though they didn't succeed in conveying their message to decision makers and making them view Hungary as a brand.

This situation was changed by the establishment of Country Brand Council in 2008, according to a government decision [2176/2008. (XII. 18.)]. In 2009 Department of Foreign Affairs, cultural institutions, offices of Hungarian Investment and Trade Development Agency, Agricultural Marketing Centre and Hungarian Tourism cPlc. were those that performed the task of shaping nation image of Hungary. These state institutions determined their marketing communication goals independently from each other, lacking a harmonised strategy. Country Brand Council, that commenced its operation with 12 independent professional experts, tried to remedy this situation with the coordination of and providing professional advices to these organisations (PAPP-VÁRY 2009/a. 14.).

In 2010, this Council was renewed and underwent a transformation in the framework of a government decision [121/2010. (X. 8.)]. According to this, Country Brand Council became a platform for reflection, advice and vocational preparation showing paths that lead to the creation of a single nation image and the shaping of a picture of the country. It initiated researches, devised strategies, monitored domestic and foreign press for analyses and professional writings, by which made summaries and studies (Nemzeti Jogszabálytár, 2010).

Apart from the president, Council performed its duties with the cooperation of 25 members designated by the Minister of Administration and Justice. Secretary of the Council was appointed by Minister of State for Social Relations. The mandate spanned a two-years term, with no compensation for the work performed (Nemzeti Jogszabálytár, 2010). Co-presidents of the Council were Deputy Minister of State for Government Communication from then Department of Administration and Justice, Borbála Papp-Váry and Deputy Minister of State for Cultural Diplomacy from then Department of Foreign Affairs, Gergely Pröhle. Members of the Council were among others historian Balázs Ablonczy, psychologist Mária Kopp, film director Csaba Káel or architect Sándor Finta. The team was enlarged by a museologist, a fashion designer, a communication expert as well as an actor, with the Council's work supported by a team competent in the area of advertisement. This institution having presented an integrated approach, that in the end numbered 20 members with almost every area represented, could have been the first governing organisation channelling nation image of Hungarians to one direction, joining different policies together (PAPP-VÁRY 2009/a).

However, voluntary nature of the initiative prevented this body from achieving a major success, although they presented a proper approach from the point of view of nation branding. Nowadays Hungarian Touristic Agency is what executes this task of harmonising.

\section{LEGAL BACKGROUND OF THE SHAPING OF NATIONAL IDENTITY AT THE TIME OF HUNGARY'S DEMOCRATIC TRANSITION AND THEREAFTER}

The ruling government proposed their early ideas concerning national and statal emblems on the 
$8^{\text {th }}$ March in 1989; relating to the Crest, the National Flag and the capital of the country. Other symbols expressing national identity were also named by them. As further ones "Himnusz", "Szózat", and as historical objects of outstanding importance the Sceptre, the Globus Cruciger, the Robe, and the Holy Right were included in their list.

The proposal didn't seem to be problematic in the case of the Flag and the capital city, however the altering of the Crest triggered numerous debates. In the end, legislation accepted provisions concerning their use. In time of national celebrations and commemorations the Flag of the Hungarian Republic have been to be hoisted in front of the House of Parliament since then.

The government ruled in 1999 wanted to enact a law to commemorate the millennium anniversary of the Founding of the State. And together with this, the Holy Crown. This was the time when the so-called "Crown Act" was codified. It emphasised that Hungarians unified with other people in Europe in Christianity. The Crown embodies the continuity, independence and unity of the Hungarian state. The Holy Crown as a historical emblem refers to that each and every citizen of the country is part of the power. It has to be put in a worthy place, taken under the protection of the National Assembly, relocated to the Parliament Building. In the wake of the National Assembly's acceptance of the act the Holy Crown as a national symbol was put into the Parliament Building's Dome Hall, according to its proper ceremonial order. Previously, Esztergom and the Hungarian National Museum gave home to it.

The armoured vehicle transporting national relics from the Hungarian National Museum was going on a protected route to Kossuth Square, the Building of the National Assembly, escorted by policemen on motorcycle. The car delivering the Holy Crown, the Globus Cruciger, the Sceptre and the Sword covered the distance between the two buildings in less than a quarter of an hour. In the end, the royal-blue coloured vehicle rolled to the main gate of the House of Parliament where a five-member body were waiting for the national relics; namely the President of the State Árpád Göncz, the Prime Minister Viktor Orbán, the Speaker János Áder, the President of the Constitutional Court János Németh and the President of the Hungarian Academy of Sciences Ferenc Glatz. The ceremony continued by the hoisting of the Flag of the Republic, followed by the voices of the Hymn and the firing of 21 salutes.

The Holy Crown, the Globus Cruciger, the Sceptre and the Sword were put in a special storing place set up in the Parliament Building's Dome Hall. In the storing place, that was built from 28 million Hungarian Forints and installed with special security equipment of a value of 15 million, the Crown and Crown Jewels are protected from natural light, besides special lights prevent from shadow being thrown to them. The vitrine is earthquake-resistant, and for the protection of their state, relics are surrounded by nitrogen instead of oxygen.

\section{The hUNGARIAN hOUSE OF PARLIAMENT AS A CULTURAL VENUE}

Hungarian Parliament Building is situated in the downtown of Budapest, on the banks of Danube River, in the heart of the city. The edifice found on Kossuth Square spreads in 265 metres in length, its highest point is 96 metres long. The House of Parliament, being the third biggest parliament building in the world with a basic area of 17745,45 square metres, counts as quite a large space for holding National Assemblies, in international comparison (DúzSI - SzÉLL 
2017. 3.) The fate of this iconic structure, which is a must-see attraction for all visitors coming from within Hungary and abroad, was determined by a design contest. The winner of this competition was the work of Neo-Gothic style of a teacher at Technical University, Imre Steindl, whose office employed many contemporary prominent architects, among others Ernö Foerk, was assigned to design the building. Neo-Gothic style and construction plans of the building were heavily criticised that time, finding them old-fashioned and too historicising. However, there also were arguments for Imre Steindl's plans, one of them was that tradition of rightly famous English parliamentarism, National Assembly in England of serious tradition provided an example to Hungarian society, and its gothic style (Westminster) was a manifestation of this thought. Besides, the Houses of Parliament in London set an example to follow in an aesthetic point of view as well, reflected by the similarity of the new castle building of the Hungarian Parliament to the House of Legislation in England, regarding not only its style but also its river bank location. At that time Count Gyula Andrássy, then Prime Minister and Minister of Foreign Affairs, was the politician who was the strongest supporter of constructing the building by this plan (ANDRÁsSY 2016). ${ }^{1}$

Construction works of the House of Parliament started when the hoe hit the ground in 1885 and were completed in the year of 1902. This was the time of the First National Assembly taking place in the new building. The biggest and most expensive investment of the era attracted the press's attention as well, its size and style having been heavily criticized. The fact, however, that the construction of it revived Hungarian industry is undeniable, as materials from within the borders of then Hungary were to use together with applying the workforce of preferably Hungarian craftsmen. Glass artist Miksa Róth, furniture makers Endre Thék and Alajos Michl as well as master of wrought iron Gyula Jungfer were working on the inner and outer spaces of the edifice.

Apart from its style the choice of location of the building was also a source of heated criticism. ${ }^{2}$ Construction works were taking place in former Tömö Square that belonged to the outskirts of Budapest that time. Building material debris from 1838's flood piled up here, hence its name. Later, after the Hungarian Parliament Building had been built it was renamed to Országház ("House of Parliament") Square, than in 1927, after the inauguration of the group of statues of Kossuth made by János Horvay got its name Kossuth Square that is used still today (TöRÖK - WACHSLER 2015).

Resulting from its parliamentary function Kossuth Square hosted several prominent events which were great moments in Hungarian history. Firstly, Hungarian society witnessed proclamation of the Third Republic, on this symbolic square. Furthermore, during the years following the handover of the edifice it provided place mainly for demonstrations, later, in Horthy-era mass events for Christians were organised here, such as Eucharistic World Congress in 1938. Under communist regime, Kossuth Square became a place for representation, among others pioneers' meetings were organised, or Bertalan Farkas was welcomed here after accomplishing his travel to space. Kossuth Square is also a place for commemoration, we can remember the

It is interesting to note that at the evaluation of competition works Steindl's plan won in a draw with that of Alajos Hauszmann, but in the end - probably reasoned with the arguments mentioned above - Steindl's design was selected.

2 Then Prime Minister István Tisza was also judged on the basis its family's gaining financial benefit from the buildings's location on Tömő Square. 
victims of volley of fire in the $25^{\text {th }}$ of October in 1956 when being near the House of Parliament. On that so-called "Bloody Thursday" perpetrators having remained unknown to this day opened a volley of fire to the assembling crowd, resulting in the loss of lives of dozens of people. Today, an exhibition space set up in a ventilation tunnel provides a venue for commemoration of this day and its victims. On Kossuth Square that had hosted historical moments many community events took place; concerts were held, a skating ring was established, or Santa Claus Factory was set up (TöRÖK - WACHSLER 2015).

In 1972 United Nations Educational, Scientific and Cultural Organization (UNESCO) adopted World Heritage Convention. The institution's goal is to call attention to humankind's places of outstanding value thus protecting their safety. States joining this convention are obliged to protect the places included in the list (vilagorokseg.hu, 2018.) On the $11^{\text {th }}$ of December in 1987 Buda Castle Quarter as well as landscape of the area spread between Margaret Bridge and Liberty Bridge along the banks of Danube River, an important part of which is taken up by the House of Parliament, was taken on UNESCO's World Heritage List (Moravetz, 2016). Not only its aesthetic beauty but also its important role filled in during the time of Austrian-Hungarian Monarchy was emphasised (UNESCO 2018).

As the House of Parliament had been damaged by weather and historical vicissitudes, in 2011 National Assembly decided to reconstruct Kossuth Square in the framework of Steindl Imre Program, at the expense of 27 billion Forints. It was necessary not only because of quality problems with the stone material covering the building. It was reasoned with that the House of Parliament provides not only home for legislative power but also place for the Holy Crown being kept safe and protected, that's why it not only serves public law function but should satisfy touristic goals as well. Besides, it shares its role in tourism with the square spreading in front of it. Consequently, the main aim of reconstruction was creating a space structure more thoughtthrough than the previous one, in order to reimplement original, that time already unrecognisable, design devised by Imre Steindl. Works ended in 2017, with the inauguration of the statue of Andrássy (nemzetfotere.hu 2018).

On the $7^{\text {th }}$ of October in 2011 National Assembly accepted the Law No CXLIX/2011 about the Amendment of the Law No LXIV/2011 about the Protection of Cultural Heritage. It made Kossuth Lajos Square a national memorial place of outstanding importance from the $1^{\text {st }}$ of January in 2012 . This title is given to places that carried extraordinary relevance in national history, were decisive to their era, play important role in national or minority self-identification, strengthening Hungarians" "we-consciousness". Apart from this, they should enhance Hungary's international recognition, with nation's cultural life events taking place there elevating people's erudition. According to this law, the owner of a national memorial place of outstanding importance is the state in every case, decisions regarding Kossuth Square are made by the all-time Speaker. That is how in the wake of reconstruction works Kossuth Square was reshaped, and became a national memorial place of outstanding importance, i.e. Nation's Main Square (Nemzeti Jogszabálytár 2011). Mentality history of the Square would be worth being examined in the framework of a further research, as in my view this law provides a great example for brand building process from up to down (topdown). Although this law was created by decision makers, it didn't became a part of common knowledge, neither of public identity at local level. This process, this transformation to inner 
identity should be important to be examined and rethought with the tool of mental mapping and those of cultural anthropology.

The House of Parliament is the primary place for legislation, however, it offers a number of services to satisfy scientific and cultural interest. Cultural Heritage Days, Memorial Places' Day, Night of Museums all open the gates of the Parliament Building, with those working there welcoming visitors with a wide range of special programs. It is open to the public when conferences and book presentation events are delivered which are free to attend for all of the citizens. In addition, with the Parliament Museum having been called into being, and owing to the four exhibition spaces free to visit both domestic and foreign tourists can gain information about the House of Parliament and Kossuth Square. Guided tours for individuals or groups and related museum pedagogical sessions enrich visitors' knowledge about the history of legislation and that of construction of the Parliament. Student and youth programs are organised for highschool students with the aim of widening their knowledge in the area of pedagogy and civic education. Models and simulations provide fun ways for them to gain first-hand experience of the National Assembly, the Holy Crown, and the House of Parliament, and by founding fictitious parties they can get a taste of the joys and difficulties go with representative democracy. Apart from the Parliament Museum another public collection, namely the Library of the Parliament supports scientific work and cultural life. The Board for Public Collection and Public Education puts up the House of Parliament for sale as a cultural product integrating the fields of tourism, science and pedagogy. In the following chapters I will take the quality of these services under scrutiny, examining the results coming from the synergy of interconnected areas. My thesis is that in their micro-environment leaders of the House of Parliament recognised the need for integration that would be a prerequisite for image building and branding. The Board for Public Collection and Public Education as an organisational unit underpins this idea.

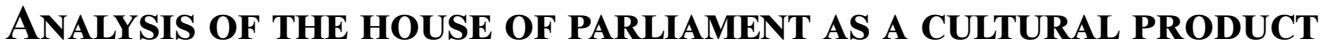

The method I used for examining the quality of services offered by the House of Parliament and Kossuth Square is SWOT analysis. It is divided into two main parts. Opportunities and threats are presumptions based on outer, environmental factors. It means that the rigidness of these factors makes it more difficult to change them. Inner strengths and weaknesses, on the other hand, are traits to be strengthened and remedied in the short term (KOTLER - KELLER 2006. 94.). The results of SWOT analysis I below show in table form, highlighting some important attributes that I'll deal with in a more detailed way. 


\begin{tabular}{|c|c|c|}
\hline & $\begin{array}{l}\text { WEAKNESSES } \\
\text { There is no single communication and market- } \\
\text { ing strategy, neither a related image within the } \\
\text { House of Parliament, as it is divided into differ- } \\
\text { ent units. } \\
\text { Extreme professionalism and the use of legal } \\
\text { language prevails in the office. } \\
\text { There is a lack in human resources (namely a } \\
\text { qualified manpower in the field of communica- } \\
\text { tion). } \\
\text { The function of the House makes the image and } \\
\text { the "spirit" of the place too dominant. } \\
\text { There is strong control exerted by the office: } \\
\text { stiffness. } \\
\text { It is primarily a place for holding National As- } \\
\text { semblies, leaving little room for other functions. }\end{array}$ & $\begin{array}{l}\text { STRENGTHS } \\
\text { It is a unique place: UNESCO. } \\
\text { Professionalism prevails (history of co-workers, } \\
\text { carpenters, upholsterers, research base). } \\
\text { It represents art-historical and historical value. } \\
\text { Modern technical solutions have been imple- } \\
\text { mented. } \\
\text { It is easily accessible from downtown. } \\
\text { There is a rise in the amount of foreign tourists, } \\
\text { it is a number one tourist attraction in Budapest } \\
\text { (advertising costs without media buying). } \\
\text { Renewed Square and House emit the atmo- } \\
\text { sphere of modernity, offering visitors a pleasant } \\
\text { environment. }\end{array}$ \\
\hline 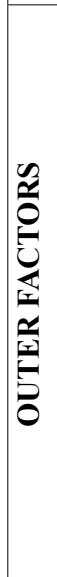 & $\begin{array}{l}\text { THREATS } \\
\text { Financial resources are difficult to access. } \\
\text { Because of the four-year cycle of elections there } \\
\text { is no room for long-term planning. } \\
\text { The place for holding National Assemblies } \\
\text { makes the capacity for the hosting of visitors } \\
\text { limited. } \\
\text { Due to security reasons enhanced safety mea- } \\
\text { sures have been implemented. }\end{array}$ & $\begin{array}{l}\text { OPPORTUNITIES } \\
\text { Event venues have been set up by the Headquar- } \\
\text { ter of Federation of Technical and Scientific So- } \\
\text { cieties. } \\
\text { In courtyard No } 3 \text { a new event and exhibition } \\
\text { space has been established. } \\
\text { Event venue found in courtyard No } 15 \text { is not } \\
\text { used enough. } \\
\text { There is a prevalence of social media in inde- } \\
\text { pendent and cultural area. } \\
\text { Kossuth Square can more frequently be used for } \\
\text { hosting programs, public events. } \\
\text { Numerous new services, special tours (noctur- } \\
\text { nal, or the one taking place in the dome) can be } \\
\text { offered. }\end{array}$ \\
\hline
\end{tabular}

The biggest strength of the House of Parliament lies in that it provides a home for artistic and historical memories as a place that sells itself by their aesthetic character traits. Visitors' main motivation is primarily to see this place as that of world heritage and only secondarily as the one for holding National Assemblies. This dualism is reflected in the managing of the House of Parliament as a cultural product, with its apparatus serving the need of Hungarian legislation, making economic, cultural and functional aspects taken less into account, often even opposite to each other. If it could be solved technically, amount of visitors arriving with touristic goals would be increased, particularly in order to generate revenue, although mass number of visitors would threaten smooth-running work of National Assemblies and restrict representatives' move within the House.

As a next point of SWOT analysis, political environment means such a source of threat that has an effect on the opinion formed of the Hungarian Parliament Building as a cultural product. With the changing of the persons of political decision makers (that of the Speaker) positioning and segmenting of cultural product can be formed. It exerts an influence primarily on Hungarians' picture shaped of the House of Parliament, as foreign tourists generally aren't aware of our 
political situation and system. However, ever-increasing attention from foreigners' part, mostly from those coming from the European political area, will give this segment a priority. In my view, the biggest opportunity of the House of Parliament lies in that by its geographical location being known it would be easy for it to become a part of Budapest's cultural and touristic life. I mean classical music events, opportunities provided by concerts held here, street music like open programs, events of Spring and Autumn Festival by this.

With using SWOT analysis opportunities of the Hungarian House of Parliament as a cultural product have been measured up. In the following section, micro-environment of the Parliament will be shown taking one step behind, with the help of STEEP analysis, taking social, technological, economic, ecological and political aspects into account.

S (social) - Social micro-environment surrounding the House of Parliament consists of residents of the $5^{\text {th }}$ District. From their point of view, the Parliament and Kossuth Square don't count as public areas, instead create a small island within the district with the local government having no authority over them. Local residents aren't properly involved in cultural life taking place in the House of Parliament, they aren't informed about opportunities and occurring events. Walking dogs on the Square is prohibited, at the same time a large number of sitting and sunbathing places have been built, coffee houses are opening continuously, having made the Square in summer months packed with people time and time again.

T (technological) - The House of Parliament is extremely well equipped technically with the most cutting-edge tools, due to its reconstruction, in order to meet security expectations. On the other hand though, it lags one step behind as far as the latest trends are concerned: a main stage, an event tent and concert tools are to be obtained from outer source.

E (economic) - From an economic point of view, the Parliament Building is in a prominent position, given that a huge amount of financial resources is earmarked annually for its maintenance. Revenue generated by tourism is ploughed back to the development of quality services offered here. Owing to this, projects that don't cover primarily profit-oriented activities can also be funded, such as student programs or "Square-Music" concerts which can be participated in and enjoyed free of charge, furthermore, Visitor Centre can also be developed and enlarged. (Rebuilding works are taking place even these days.)

E (ecological) - During its reconstruction the House of Parliament and its surroundings were undergoing a complete change ecologically. Since vehicles were forbidden from the Square and bicycle lane was fortified, visitors have been provided with environmentally conscious traffic opportunities. The plantation of a new garden served the goal of embellishing the Square with endemic plant species.

$\mathbf{P}$ (political) - Kossuth Square and the House of Parliament are national memorial places of outstanding importance, as it was mentioned previously, the owner of them is not the $5^{\text {th }}$ District but the state. In this present case, permitting the use of the Square and the holding of events falls within the competence of the all-time Speaker.

Having examined the environment of the House of Parliament and the services offered there I will now make a suggestion regarding target groups who are affected by them. The first one is made up of those who come to visit with pedagogical aim, students (reached through 
pedagogues) and teachers. Apart from this, a prominent target group of the Parliament consists of the age group of those retired, whose main points of interest are the two public collections and visiting the Parliament Building on occasions of special events. Audience made up of professionals (those belong to upper layers of society who are culturally cultivated and have art-historical interest) and tour operators, i.e. travel organisers, also play an important role in mediating services. It is also important to remember that as the House of Parliament is the place for legislation, delegations are to be considered target groups in the same way as representatives. Last but not least, it is the tourists to whom Visitor Centre and services related to the visiting of the House of Parliament have mainly been positioned.

Information about services reaches target groups through online and offline channels. Online communication tools are made up of four main factors-websites, social media (Facebook, Instagram), Youtube channel, mobile applications-complemented with notifications sent via email functioning as newsletters. Quality of websites shows a wide variety, parlament.hu is a site where all information is available both in English and Hungarian. However, given that it is a collection page touristic and cultural services are lost in the flow of information, not to mention that as far as quality of its design and web design is concerned it needs to be streamlined. Besides parlament.hu there are several smaller websites, such as nemzetfotere.hu, inmemoriam1956.hu, szabadsagkodjai.hu or ogyk.hu. So that readers have access to cultural content in one place, different contents should be harmonised.

Facebook pages show a more complex picture. Both public collections (Library and Museum) have their own Facebook page, as both Hungarian National Assembly and the Hungarian House of Parliament have their own social media profile. In addition, student programs and podium talks (Pulpitus) have their group or so-called circle of friends on Facebook. It would be worthwhile to write concise posts of a maximum of forty characters on social media platforms and use them as a transit zone embedding articles published on websites. For imparting information more effectively, it would be practical to include infographic tools, such as gifs and hashtags, in the portfolio published on social media.

Communication platforms of cultural content of the House of Parliament are the following: 1. One-way

a) Websites

- parlament.hu

- nemzetfotere.hu

- ogyk.hu

- http://latogatokozpont.parlament.hu

- $\quad$ http://parlament.hu/infoszolg

- orszaggyulesimuzeum.hu

- $\quad$ inmemoriam1956.hu

- $\quad$ szabadsagkodjai.hu

- $\quad$ konseta.parlament.hu 
b) Videos

- $\quad$ about the Library, nemzetfotere.hu

- Youtube channel: “Országház, Közönségszolgálat” ("House of Parliament, Public Relations")

2. Two-way

a) Direct
E-mails
Mailing lists
Newsletters

b) Indirect

Social media sites: Facebook, Instagram

The House of Parliament conveys its message to its target groups via channels in its own operation, although representatives pursue only direct marketing activities. They don't use classic ATL marketing tools (TV ads, citylight, giant posters), targeting tourists or Hungarian citizens. Branding activity pursued by the House of Parliament is not comprehensive. Institutional background for the improvement of this process have already been established (Board for Public Collection and Public Education), although a comprehensive strategy is necessary also here for the accomplishment of long-term goals. The process of cultural building is aggravated by the fact that the House of Parliament fills in the function of the place for legislation as well, with non-negligible political content.

\section{THE HOUSE OF PARLIAMENT’ ROLE IN TOURISM}

The House of Parliament and Nation's Square are visited by hundreds of those interested on a daily basis, tourists and Hungarians, politicians and foreign delegations as well. It undeniably plays an important role in tourism, which has further been strengthened since reconstruction works ended. Until 2017 when the project came to its end, the paving of the Square had been changed completely, in the place of a surface parking lot an underground garage had been established (with a space capacity of nearly 600 vehicles). The opening of the underground Visitor Centre solved the task of serving those interested at $21^{\text {th }}$ century level. Before that, long rows of visitors were snaking on the uncovered Square trying to get into the Parliament Building. Today tickets are available in a modern way, through Visitor Centre designed by Zoltán Tima. In addition to this, those who want to avoid standing in long queues have the possibility of buying their tickets online. In Visitor Centre a café bar, a gift shop and two exhibition spaces have been set up providing the opportunity for visitors to widen their knowledge of the thousand-year history of legislation and the House of Parliament's construction. These venues are adequate even to arranging events there (Office of Parliament 2018).

During the course of reconstruction, environment of landscape architecture around Kossuth Square was undergoing a complete change, furthermore, community spaces have been established and free exhibitions have been launched. In two former ventilation tunnels exhibition 
spaces have been set up in memory of 1956's victims of volley of fire together with a stone collection exhibiting special pieces of stone carving and architecture that can hardly be seen with naked eye on the edifice. Since reconstruction works were completed, there's been a continuous increase in the number of those coming to see the House of Parliament; in 2013 amount of visitors were 394 128, which in 2016 rose to nearly 582 930. 2017 witnessed this same dynamism, with more than 600000 (exactly 647255 ) of those interested having come to see the Hungarian Parliament, 80 percent of whom having arrived from abroad (Office of Parliament 2018).

The Building of Hungarian Parliament enjoys unbroken popularity, a social travel magazine titled TripAdvisor put it on its 2017's list presenting the most popular sights in Europe to the $7^{\text {th }}$ place, before such world-wide liked attractions like the Big Ben, the Notre Dame in Paris, or even the Acropolis. In the list of world's most popular sights the House of Parliament gained a prominent, namely the $14^{\text {th }}$ place (TripAdvisor 2017). However, the House of Parliament was considered popular not only by TripAdvisor's ranking list, but is also included in tourist and travel agencies' offer as a general favourite, as a symbol representing Hungary.

Nation image depicted in Hungarian publications in the tourism field was examined in the turn of the millennium by two cultural anthropologists, in the framework of an international comparative study. They took brochures of Hungary compiled by then mainstream travel agencies under scrutiny, trying to find answer to the question of what kind of a national identity these publications suggest. Budapest was symbolized by widely-known historical monuments; the Castle, Heroes' Square and the House of Parliament were included in almost all of them, in some cases complemented with Margaret Island and Váci Street (KAPITÁNY 2001. 51-52.).

Viewing touristic offers published 17 years later online I think nothing much has changed. In big travel agencies' online offers concerning our homeland the view of the Danube and the House of Parliament was the most widely presented. It's time to do a new research taking representative samples under scrutiny that makes a comparison between central guidelines regarding nation image and tourist offers related to Hungary. Harmonising these two areas would be given a high priority considering that services provided by travel agencies are primary channels of the country' reputation.

\section{The House of Parliament as a Part of national identity}

Previously, I showed the House of Parliament as a cultural venue from a historical perspective and the point of view of service marketing. Viewing all this as a complete whole now I examine the relation between the House of Parliament and Hungarians' national identity. What visitors' number described in previous chapter indicates is that the amount of those coming to see the House of Parliament, both from abroad and within the country, is in a dynamic increase. This phenomenon is a result of complex factors. It is due primarily to that there's been a tendency to show legislative power as being open to the public. Conferences, podium talks, book presentations, open days provide opportunities for those interested to discover new segments of the building and legislation time and time again. ${ }^{3}$ In addition to this, Hungarians have long been

These programs and cultural products are offered in Hungarian language presently. These cultural values would be worth being mediated to foreigners strenghtening the House of Parliament's feature as being open to the public. In this chapter, however, I examine Hungary's country image, from this point of view it carries no relevance. 
provided the opportunity to see the Holy Crown free of charge on every national holiday. Apart from this, every school and kindergarten group can participate in the visiting of the House of Parliament without no entrance fee, bound to registration, guaranteed free travel opportunity.

For Hungarian society as a whole the House of Parliament is a symbolic place, that of the Holy Crown and statehood, an important place of Hungarian independence. It makes a part of Hungarian people's self-image that once in their lifetime they visit the Parliament, with the aim to see primarily the Holy Crown and secondarily the building itself. (By contrast, for those arriving with touristic goals aesthetic quality is the most relevant attractive force, as in most of the publications and books in the tourism field Budapest and Hungary are popularised with the view of the Danube and the Hungarian Parliament Building. The fact that Crown Jewels are also be found here doesn't seem to make an important part in foreigners' interest toward the country.

What role does the House of Parliament play in Hungarians' national identity? Does it constitute a part in collective nation-consciousness? National feeling is a result of a complex process of rites, community events, symbols, emblems, objects, symbolic acts and historical memory. All these contribute to the creation of group cohesion, making people feel belong to one nation. National symbolics are an important pillar of national identity; the Anthem, the Flag, and the Crest constitute a part of Constitutional Law, their relevance isn't questioned by anyone. However, all the other symbols of the Hungarian cannot be circumscribed as easily (PAÁr 2016, JANCSÁK 2020).

In the late 1990's Ágnes Kapitány and Gábor Kapitány, a married couple of cultural anthropologists, were conducting a large-scale research project about the symbols of the Hungarian. According to their view, it is through symbolic meaning of objects and people that we are connected to a system wider than us, even unaware. It binds us to the "collective unconsciousness" in which we can find our own identity. It helps us separate from the others, from the other nation or subculture, drawing a border line between its user and the person or group in some aspect different from them. In their publications authors strive to show symbols of the Hungarian that helps shaping proper national self-consciousness objectively (KAPITÁNY - KAPITÁNY 2002. 9-13.).

In the Kapitánys' research both the Parliament Building and Kossuth Square are included, in the framework of an extended questionnaire. Their question was as follows: "Which one of the following public buildings do you think represents the Hungarian most appropriately?" Apart from the House of Parliament, Buda Castle, Matthias Church, Fisherman's Bastion, National Museum, Saint Stephen's Basilica, and Hungarian Academy of Sciences places found in the countryside were also included in the list, such as Pannonhalma Abbey, Esztergom Basilica, Great Church of Debrecen, Votive Church of Szeged, Eger Castle or Verecke Memorial. It is interesting to note that "future" National Theatre being built that time was also taken on the list (KAPITÁNY - KAPITÁNY 2002. 264.). If this research was conducted these days, composition of the list would certainly change. 57,7 percent of respondents marked the Parliament revealing that the edifice designed by Imre Steindl constitutes a part of Hungarians' national identity. Buda Castle gained the second place, only with a proportion of 32,5 percent though, while as the third most characteristic public building Eger Castle was selected (30,2 percent). This latter is explained by the fact that the novel of Géza Gárdonyi titled "The Stars of Eger" is widely popular amongst Hungarians. Consequently, as more than half of respondents identify themselves 
with the Building of Hungarian Parliament, it undoubtedly makes a part of national identity (KAPITÁNY - KAPITÁNY 2002. 74.).

By contrast, amongst the answers given to the question related to illustrious public places Kossuth Square proved to be less attached to national identity. Not only Heroes' Square, Buda Castle and Ópusztaszer Heritage Park came before that, but also National Museum, Visegrád Castle, Gellért Hill and Batthyány's Sanctuary Lamp. Only 17 percent of respondents felt Kossuth Square a place symbolising the Hungarian (KAPITÁNY - KAPITÁNY 2002. 265.). This result took me and also the researchers by surprise, as public spaces counting as representative places (Gellért Hill, Kossuth Square, Bem Square) appeared only marginally. This was explained by the Kapitánys with that in the whole course of research symbols of national memory attaching to 1956 showed this tendency, with hardly any vote given to them. Although Kossuth Square is a part of Hungarians' self-image, it primarily constitutes the pillar of the memory of 1956's Revolution instead of being a symbol of statehood and democracy (KAPITÁNY - KAPITÁNY 2002. 275-276.). As far as I see, answers to this research question would completely be different nowadays, this picture has been formed by the reconstruction of Nation's Main Square with related cultural events and marketing activity. Besides, I find it highly important to reexamine this when the Curia moves back to the place of Museum of Ethnography, making the symbolic unity of the three power (legislation, execution, jurisdiction) appear on Kossuth Square.

Historian, political scientist Ádám Paár calls the attention in his study to that the Parliament Building is a prominent place of connection to the West. The researcher highlights the British parallel to the House of Parliament, as was shown in the historical part of my thesis, pointing out to that Hungarian Parliament was built by the design of its London counterpart, the relevance of which was to emphasise even that time. However, Western sample, referring to England's democratic past as an example didn't emerge in symbolic space arrangement, Imre Steindl and his team at the architectural office use number symbolism there. During the course of planning, for example, they chose 96 metres as the height of the Dome referring to the millennial anniversary, the history of Hungarians, and the conquest (PAÁR 2016). This symbolic number appears in the main flight of stairs: a prominent guest (an ambassador, a delegation member) have to take exactly that many steps upward from the main entrance to the Dome Hall (DúzSI - SzÉLL 2017).

The House of Parliament constitutes a part of Hungarians' national identity, attested by its pictorial representations: numerous reproductions have been made portraying it, articles of personal use, ornamental pieces are constantly emerging. In the world of Web 2 thousands of photos are taken and videos are made of the Parliament, primarily by tourists, though. In the next chapter I'll show interpretations of the Parliament Building appearing on objects, and how Hungarians' national image is reflected through reproductions.

\section{SUMMARISING THOUGHTS}

The House of Parliament and Kossuth Square spreading in front of it, as a result of Steindl Imre Program commenced in 2011 according to the goals set by the authority of the state, became Hungarian Nation's Main Square. As a justification of reconstruction the Parliament is referred to not only as a home for legislative power but also a place where the Holy Crown is kept safe 
and protected, thus besides its public law functions it has to meet touristic expectations together with being a source of Hungarian society's erudition and identity. In the wake of reconstruction, in 2017 Kossuth Square became a national memorial place of outstanding importance that made it a more open community space after having been used as a parking lot for officials' and representatives' vehicles.

Can Kossuth Square be the Nation's Main Square? This iconic place has always performed an important role in the life of Hungarian society, particularly in the twentieth century. It witnessed the proclamation of the Third Republic, as in Horthy-era, mass events organised by the Christian Community, and in 1938 the Eucharistic World Congress. Interestingly, in this current year, in 2021 when Hungary organised this event again a commemoration was held, although main ceremony involving the Pope's visit was delivered on Heroes' Square that is another symbolic place, according to the results of researches conducted to this day.

Victims of volley of fire in the $25^{\text {th }}$ of October in 1956 are also attached to the Square, a memorial established has been holding the memory of "Bloody Thursday's" innocent victims since then. Under communist regime, Kossuth Square was a scene of representation where receptions, protocolar events, pioneers' gatherings were taking place, among others Bertalan Farkas was welcomed here by leaders of the party after accomplishing his travel to space. National character of the Square wasn't found even after the change of regime, instead, events, such as concerts, were organised to make the place spread in front of the House of Parliament more open to the public, beside Santa Claus Factory and a skating ring having been set up. It only almost acquired a solid function and image, still, it attracted tourists as well as domestic visitors.

Nowadays numerous visitors come to the Square and the House of Parliament, from within Hungary and abroad as well, events occurring here succeed in popularising architectural and touristic strengths, however as an element in Hungarians' national identity, particularly amongst the young, dominance of the processes taking place in the building against its relevance and role played in historical past leaves room for improvement for the Board designated for this task and the Hungarian political elite. Rhetoric and behaviour presented by this latter leaves a stronger mark on the process of the young's enculturation.

It would be worth to rethink service development on the model of Visitor Centre in United States Capitol as the process of American legislation and the building where it takes place is shown there by an interactive and professionally impeccable way. Capitol, the same way as the Hungarian Parliament Building, plays an important role in the shaping of nation image, parallels and differences between these two establishments should be worth being examined in the framework of a study.

\section{REFERENCES}

Andrássy, Dorottya (2016): Az Országház építéstörténete ("Construction History of the House of Parliament”). Budapest, Office of Parliament.

Anholt, Simon (2005): Anholt National Brand Index: How Does the World See America? Journal of Advertising Research. September, 2005. DOI: 10.1017/S0021849905050336 
Balatoni, Monika (2018): Országmárka vagy országimage? ("Nation Brand or Nation Image?”). In: Bába, Iván ed.: Közszolgálati Protokoll 1. ("Public Service Protocol 1.”).

CsIllag, GÁBor (2000): Greetings from Hungary. In: Zoltán, Fejős ed.: Turizmus és kommunikáció ("Tourism and Communication”). Museum of Ethnography, Budapest. 83-95.

Dúzsi, Éva - SzÉLl, SzILVIA (2017): Országházi Kalauz (“A Guide to the House of Parliament”). Budapest, Office of Parliament.

EU-vonAL (2013): Észtország ("EU-Line: Estonia“). http://www.euvonal.hu/index. php?op=mindennapok_tagallamok\&id=21 https://www.euvonal.hu/tagorszagok/esztorszag/ (Last download: $30^{\text {th }}$ April, 2021)

HuszTi, Vera (2003): A marketing általános kérdései (“General Questions of Marketing”). http:// www.omikk.bme.hu/collections/mgi_fulltext/marketing/2003/11/1101.pdf(Last download: $10^{\text {th }}$ September, 2021)

JANCSÁK, CsABA (2020): Történelmi emlékezet és a család. ("Historical Memory and Family”) In: A.Gergely, András - Kapitány, Ágnes - Kapitány, Gábor - Kovács, Éva - Paksi, Veronika (szerk.) Kultúra, közösség és társadalom. Budapest, Magyarország: Társadalomtudományi Kutatóközpont, Magyar Szociológiai Társaság. 141-159.

JENES, BARBARA (2010): Az országimázs fogalmának szakirodalmi megközelítései (“Approaches of the Concept of Nation Image in Literature”). Budapest, MOK. 1004-1012.

KAPITÁNY, ÁGNES - KAPITÁNY, GÁBOR (2002): Magyarságszimbólumok (“Symbols of the Hungarian”). Budapest, European Institute of Folklore.

KAPITÁNY, ÁGNES - KAPITÁNY, GÁBOR (2001): Magyarságszimbólumok idegenforgalmi kiadványok tükrében ("Symbols of the Hungarian Reflected in Publications in the Tourism Field"). Jel-Kép. 3. 51-71.

Kilduff, Kerry - Tabales Núnez, Julia M. (2016): Country Branding and its Effect on the Consumer in the Global Market. Cuadernos de Gestión. 17/1.

Kotler, Philip - Keller, Lane Kevin (2006): Marketingmenedzsment ("Marketing Management"). Budapest, Akadémiai Kiadó.

Kozma, BoglárKa (2004): Turizmusmarketing (“Tourism Marketing”). Budapest, Business School Faculty of Commerce, Catering and Tourism.

KSH a) (“Central Statistical Office” / a) (2018): Közvetlen külföldi müködötöke-befektetések ("Direct Foreign Working Capital Investments"). http://www.ksh.hu/docs/hun/xstadat/xstadat eves/i_int044b.html (Last download: 12 ${ }^{\text {th }}$ September, 2021.)

KSH b) ("Central Statistical Office" / b) (2018): A külkereskedelmi termékforgalom értéke forintban és értékindexei a fontosabb országok szerint ("Value of External Trade in Goods in Hungarian Forint and its Value Indexes According to Relevant Countries"). https://www.ksh.hu/ docs/hun/xstadat/xstadat_eves/i_qkt019d.html (Last download: 12 ${ }^{\text {th }}$ September, 2021)

Moravetz, Orsolya (2016): Idötlen érték - közel s távol ("Timeless Value-Close and Far"). In: nemzetfotere.hu, $11^{\text {th }}$ December 2016 15:52 http://www.nemzetfotere.hu/blog/posts/idotlenertek-kozel-s-tavol (Last download: $30^{\text {th }}$ December 2017) 
NAGY, BEÁTA (2008): Egy ország a világ szemében. Tér és Társadalom (“A Country in the Eye of the World.”). 22/4. 205-219. http://epa.oszk.hu/02200/02251/00033/pdf/EPA02251_Ter_es_ Tarsadalom2411.pdf (Last download: 13 ${ }^{\text {th }}$ September, 2021)

NAGY, KRISTÓF (2017): Rekord a külföldi befektetésekben ("Record in Foreign Investments"). In magyaridok.hu. 23 ${ }^{\text {th }}$ May, 2017. 09:44 https://magyaridok.hu/gazdasag/rekord-kulfoldibefektetesekben-1730695/ (Last download: $13^{\text {th }}$ September, 2021)

NBI (2018) http://nation-brands-gfk.com/ (Last download: 04 ${ }^{\text {th }}$ March 2018)

NemzetFotere.Hu (2018): Tér-Idö ("Space-Time”). http://www.nemzetfotere.hu/ter-ido (Last download: $13^{\text {th }}$ September, 2021)

Nemzeti JogszabÁLYTÁR (2010): 1212/2010. (X. 8.) kormányhatározat az Országmárka Tanács létrehozásáról ("National Collection of Regulations (2010): Government Decision 1212/2010. (X. 8.) about the Establishment of Country Brand Council). http://njt.hu/cgi_bin/njt_doc. cgi?docid=134244.251940 (Last download: $13^{\text {th }}$ September, 2021)

Nemzeti JogszabÁLYTÁR (2011): 2011. évi CXLIX. törvény a kulturális örökség védelméröl szóló 2001. évi LXIV. törvény módosításáról ("National Collection of Regulations (2011): Law No CXLIX/2011 about the Amendment of the Law No LXIV/2011 about the Protection of Cultural Heritage").

Office of Parliament (2018): Based on statistics and sources made by Board for Public Collection and Public Education.

PAÁR, ÁDÁM (2016): A közösségi szimbólumok és rituálék szerepe a magyar nemzeti identitásban ('Role of Community Symbols and Rites in Hungarians' National Identity"). Kultúra és Közösség 7/4. 37-57. http://www.kulturaeskozosseg.hu/pdf/2016/4/04.pdf (Last download: 30 ${ }^{\text {th }}$ January 2018)

PAPP-VÁRY, ÁRPÁD FERENC (2006): Az országmárkázás elmélete és gyakorlata (“Theory and Practice of Country Branding"). rekláMérték 4/34.

PAPP-VÁRY, ÁRPÁD FERENC (2007): Az országmárkázás szerepe és hatásai: országimázs a kibövült Európai Unióban ("Role and Effects of Country Branding: Nation Image in Enlarged European Union"). Book of a Doctoral Thesis, Sopron.

PAPP-VÁRY, ÁRPÁD FERENC (2009/a): Országmárkázástól a versenyképes identitásig. A country branding megjelenése, célja és természete. ("From Country Branding to Competitive Identity. Appearance, Goal and Nature of Country Branding.") Marketing és Menedzsment 2. 4-19.

PAPP-VÁRY, ÁRPÁD FERENC (2009/b): Újragondolt országimázs. ("Nation Image Rethought."). Marketing és Média 1-14 ${ }^{\text {th }}$ April, 2009. 14-15.

PATAKI, FERENC (2001): Élettörténet és identitás ("Life History and Identity”). Budapest, Osiris Kiadó. http://www.szaktars.hu/osiris/osiris/view/pataki-ferenc elettörtenet es identitas-2001. (Last download: $10^{\text {th }}$ September, 2021)

R. HAhn, VeroniKa (2013): Bajban a Magyar imázs. In: NOL.hu.2013.10.27. (Last download: $15^{\text {th }}$ September, 2021) 
SAME, SIIRI (2014): Experience Marketing in Country Branding: Theoretical Developments and an Estonian Case Study. Research in Economics and Business: Central and Eastern Europe 6/1. 65-89.

SzÖRÉNYI, ANDRÁs (2009): Smart power, avagy az év „felfedezése” (“Smart Power or 'Invention' of the Year"). Külügyi Szemle 8/3. 147-158. http://kki.hu/assets/upload/Kulugyi Szemle_2009_03_Smart_power_avagy_az_ev.pdf (Last download: 30 ${ }^{\text {th }}$ July, 2021)

Terry, ANDrew - Forrest, Heather (2008): Where's the Beef? Why Burger King is Hungry Jack's in Australia and Other Complications in Building a Global Franchise Brand. Northwestern Journal of International Law and Business 28/2. 170-214.

https://scholarlycommons.law.nortwestern.edu/cgi/viewcontent.cgi?referer=http:/www.news. com.au/\&httpsredir=1\&article $=1667 \&$ context $=$ njilb (Last download: $19^{\text {th }}$ July, 2021)

TózsA, IstváN (2012): Mi az országimázs? (,What is Nation Image?”). Turizmusonline.hu. $25^{\text {th }}$ November, 2012. 09:02 http://turizmusonline.hu/aktualis/cikk/orszagimazs (Last download: $18^{\text {th }}$ July, 2021)

TÖrÖK, ANDRÁs - WACHSLER, TAMÁs (2015): A nevezetes magyar Országház, és a tér, ahol áll (,The Famous Hungarian House of Parliament and the Square where it Stands on”). Osiris Kiadó, Budapest, Office of Parliament.

Tradeforum.org (2018): Is There a Case for National Branding? http://www.tradeforum.org/ Is-There-a-Case-For-National-Branding? (Last download: $30^{\text {th }}$ July, 2021)

TripAdvisor (2017): A világ 25 legnépszerübb látnivalója ("The 25 Most Popular Sights of the World"). https://www.tripadvisor.co.hu/TravelersChoice-Landmarks (Last download: 30 December, 2020)

Turizmus Bulletin (2006): Magyarország imázsa a GMI Nation Brands Index alapján (Hungary’s Image by GMI Nation Brands Index"). 4. 28-33.

UNESCO (2018): Budapest, Including the Banks of the Danube, the Buda Castle Quarter and Andrássy Avenue, https://whc.unesco.org/en/list/400 Last download: 30 ${ }^{\text {th }}$ July, 2021

VilagoroKSEG.Hu (2018): Our World Heritage Sites. http://www.vilagorokseg.hu (Last download: $17^{\text {th }}$ August, 2021)

ZENTAI, ANDRÁs (2015): Nemzeti értékeink megörzése. A hungarikumok és a köréjük szervezödö rendezvények Magyarországon és külföldön ("Protecting Our National Values. Hungaricums and Events Organised Around Them in Hungary and Abroad). Budapest Business School. 